\title{
Assessing the potential for managed aquifer recharge (MAR) of the Cape Flats Aquifer
}

\author{
B Mauck ${ }^{1}$ and K Winter ${ }^{1}$ \\ 'Department of Environmental and Geographical Science, South Lane, Upper Campus, University of Cape Town, Rondebosch, South Africa
}

This paper discusses the potential use of 'managed aquifer recharge' (MAR) in Cape Town to provide additional water supplies to the city that are fit-for-purpose. The paper investigates the feasibility of implementing MAR by simulating the artificial recharge of winter stormwater into the Cape Flats Aquifer (CFA), an extensive sandy, unconfined aquifer that covers most of metropolitan Cape Town's urban landscape. The objective is to assess the storage capacity and supply potential of two MAR sites by modelling various scenarios in order to determine the feasibility of MAR as a viable strategy for achieving improved water security by augmenting groundwater water supply. The selected scenarios demonstrated that MAR could be used to minimise the risk of seawater intrusion and maximise the amount of water available for abstraction from the CFA. Six MAR scenarios provided strong evidence to suggest that there is sufficient storage capacity within the CFA for using stormwater to improve the wellfield yield in two regions of the CFA and which can sustainably yield approximately $18 \mathrm{Mm}^{3}$ per year. The study concluded that the use of stormwater or treated wastewater could be deliberately used to recharge the CFA and as a viable option in support of the City of Cape Town's intention to establish a water-resilient city by 2030 .

\section{INTRODUCTION}

Since 1996, Cape Town's population has increased by $56 \%$, which has added to the city's strained water supply and demand (CoCT, 2017). The city is situated in a water-scarce region and is almost entirely dependent on winter rainfall for surface- and groundwater supplies (Currie et. al., 2017). Approximately $94 \%$ of Cape Town's water supply is from large surface-water storage dams that are situated outside the city's municipal boundaries and fall under the jurisdiction of the National Department of Water and Sanitation (Sinclair-Smith and Winter, 2019). The remaining 6\% is obtained largely from groundwater abstraction (CoCT, 2020).

The overreliance on stored surface water was severely tested between 2015 and 2018 when the Western Cape Province of South Africa experienced three consecutive years of below-average rainfall with a return interval of 1:311 years, and in which 2017 was the lowest rainfall on record (Wolski, 2018). By early 2018, the total volume of stored water for Cape Town, agriculture and surrounding towns had fallen to below $30 \%$, with at least 4 dry months ahead before the expected winter rainfall. The potential for a major city to run out of water was captured in the infamous term, 'Day Zero' - the day when the amount of stored water would fall to below $13.5 \%$ and large sections of the city would be without piped water. Over 4 million people would then be forced to queue for their daily rations of $25 \mathrm{~L} \cdot$ day $^{-1}$ from planned distribution sites across the city. Fortunately, Day Zero was averted by a combination of factors such as water demand management (WDM) strategies (CoCT, 2019); severe restrictions imposed on water use on the agricultural sector; and compliant citizens who reduced their water demand on the municipal water supply (Enqvist and Ziervogel, 2019). The water crisis presented the City of Cape Town (CoCT) with an opportunity to develop a new water strategy which is supported by five key commitments. One of these commitments is to diversify its sources of water supply by including the use of stormwater, treated wastewater and desalination (CoCT 2019). The strategy sets out to enable Cape Town to become a water-resilient city by 2030 and a water-sensitive city by 2040 . The plan is also to enhance the aesthetic and recreational value of waterways and to improve biodiversity, habitat and ecosystem services (CoCT 2019). The success of the new water strategy will require a holistic approach that seeks to close the loop on the urban water cycle in the city and to ensure that every drop counts.

One area of interest in urban water management is the practice of managed aquifer recharge (MAR), which is used in a number of countries, such as the United States of America, India, Netherlands, Australia and Israel, for enhancing groundwater supplies for maintaining the urban water balance (Murray et al., 2007). MAR includes the practice of deliberately recharging aquifers to increase stored water capacity and groundwater supply (Dillon et al., 2009). However, the feasibility is largely dependent on the characteristics of the aquifer in its ability to store, to support the interflow of groundwater after recharge and to allow the abstraction of water without damaging the underlying soil and geological structure. There are potential risks in the use of MAR. For example, over-abstraction can result in sinkhole formation in dolomitic aquifers and the subsidence of surface land from excessive dewatering (Murray et al., 2007; Dillon et al., 2009; Page et al., 2013). Nevertheless, an overriding motive for implementing MAR is to improve water supply for multiple purposes and improved support for ecological systems and services.

The aim of this paper is to investigate the feasibility of implementing MAR in a sandy, unconfined section of the Cape Flats Aquifer (CFA) in Cape Town by simulating the artificial recharge with stormwater, and to assess the potential storage and supply potential by modelling the MAR to describe a series of scenarios.

\section{CORRESPONDENCE}

K Winter

EMAIL

kevin.winter@uct.ac.za

\section{DATES}

Received: 23 February 2020

Accepted: 24 September 2021

\section{KEYWORDS}

managed aquifer recharge (MAR)

stormwater

Cape Flats Aquifer

\section{COPYRIGHT}

() The Author(s)

Published under a Creative

Commons Attribution 4.0

International Licence

(CC BY 4.0) 


\section{Study site}

The Cape Flats is a coastal sandy plain that extends over an area of approximately $400 \mathrm{~km}^{2}$ between False Bay to the south, the Tygerberg Hills in the north, Table Mountain to the west, and the hills of Brackenfell to the east (DWAF, 2008). The topography of the Cape Flats ranges from 0 to $45 \mathrm{~m}$ amsl, whereas the surrounding topography is marked by significant changes in elevation reaching $1080 \mathrm{~m}$ amsl at its highest point (DWAF, 2008). Mountainous areas receive significantly more rainfall $\left(>1000 \mathrm{~mm} \cdot \mathrm{yr}^{-1}\right)$ than the lower-lying landscapes $\left(600 \mathrm{~mm} \cdot \mathrm{yr}^{-1}\right)$ (Schulze et al., 2008). The relatively flat topography of the Cape Flats aquifer (CFA) has resulted in numerous permanent and seasonal wetlands, but urban development has disturbed or resulted in the disappearance of many of these wetlands (Rebelo et al., 2011). The CFA is dominated by quaternary sand, which was deposited under fluvial, marine and aeolian conditions, and is underlain by Malmesbury Shale and Cape Granite basement rock. The Peninsula Formation overlays the basement layers of the Malmesbury and Cape Granite, forming a major unit of the sedimentary sequence of the Cape Supergroup. This group is not found in the Cape Flats area due to extensive erosion, but is present in other parts of the Cape Peninsula where it forms topographic features such as the Table Mountain range (DWAF, 2008). The highest storage or MAR potential is found in the southern regions of the CFA, near Philippi and Mitchells Plain (Fig. 1). The MAR potential concept is understood as the storage that is available but unused due to a lack of natural recharge and abstraction. Since there is no detailed observation over the entire CFA, the study uses baseline model information as an indication of the natural aquifer characteristics to estimate the MAR. The method demonstrated by Murray et al. (2007) was used to calculate the MAR potential of the CFA and assumes that MAR is most suitable in an aquifer where there is an additional storage volume due to lack of natural recharge. The MAR Potential, which is described later in the paper, was calculated as half the difference between the 'top of the aquifer' and $5 \mathrm{~m}$ below the mean groundwater level. The top of the aquifer, which is the theoretical maximum groundwater level, was determined by simulating the groundwater levels using an artificially high rainfall data set using the Danish Hydraulic Institute's MIKE SHE and MIKE 11 models.

\section{RESEARCH METHOD}

The section discusses the application of the MIKE SHE and MIKE 11 models at a regional-scale and a local-scale, including the data, model parameterisation and the development of a conceptual hydrogeological model. The calibration and validation procedures are described together with a selection of important conceptual assumptions. MIKE SHE is a fully integrated surface and groundwater model that is capable of representing a number of surface water processes, including evaporation and overland flow, and can be linked to MIKE 11 for channel flow modelling and for simulating subsurface hydrological processes such as unsaturated flow and saturated groundwater flow. A simplified schematic shows the main components of the model (Fig. 2).

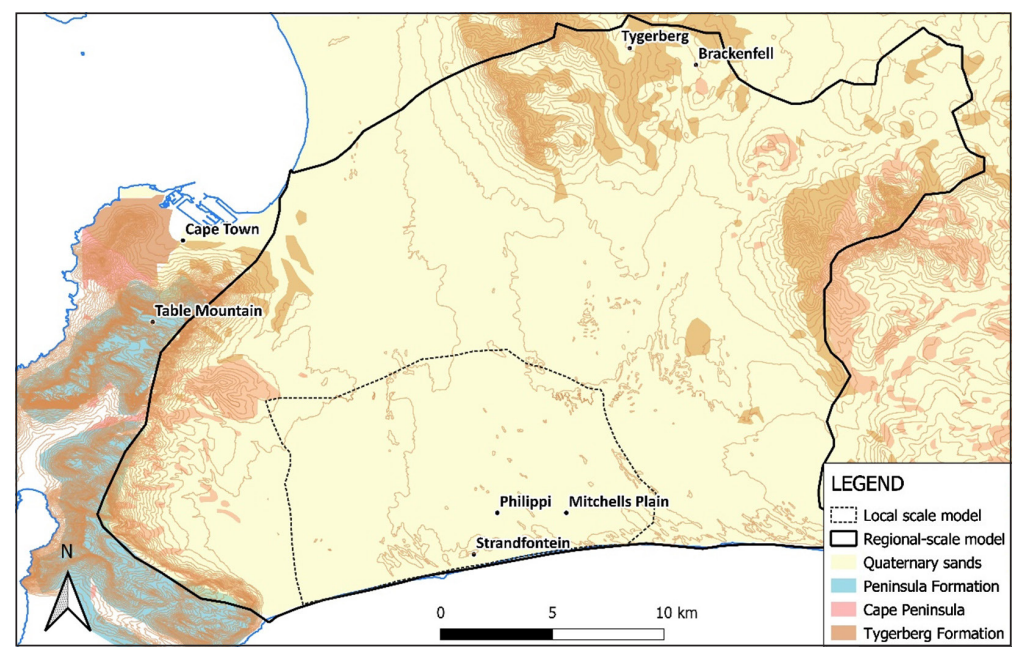

Figure 1. The geology and elevation of the Cape Town area showing Quaternary sands of the CFA (regional scale)

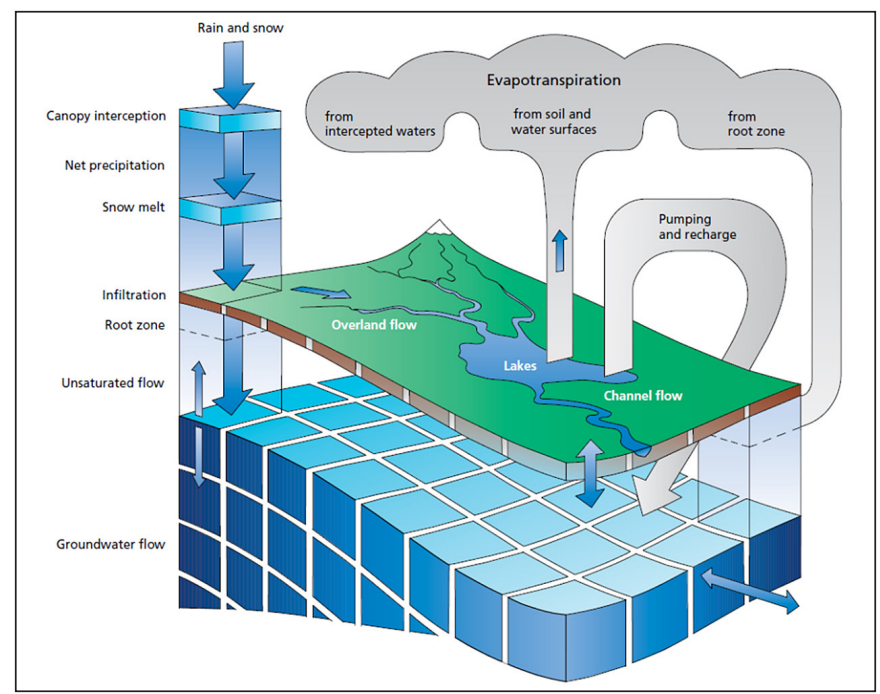

Figure 2. A schematic diagram of the MIKE SHE model (DHI 2014) 


\section{Data sources}

A combination of MIKE SHE and MIKE 11 was used to simulate the surface and groundwater processes of the Cape Flats area from 1980 to 1984 . This period was chosen because of the availability of sufficient surface and groundwater observations. The localscale MIKE SHE model focused on a detailed representation of the hydrogeological processes of the CFA in order to simulate a selection of MAR scenarios. The local-scale model was used to validate the conceptual model for the period from 2000 to 2015 using a variety of data sources required by the model (Table 1 ).

\section{Conceptual model and assumptions}

The conceptual model for this study is based on the work by DWAF (2008) that describes the 'typical' stratigraphy for the Cape Flats at a regional scale. The study concluded that at a regional scale the unconsolidated deposits could be reasonably classified into two layers, with coarse sediments below sea-level and finer peaty sediments above sea-level. However, after testing this interpretation using a numerical model, the best results were achieved using a 3-layer conceptual model. DWAF (2008) outlined a 4-layer conceptual hydrogeological model consisting of a 1-meter-thick top layer to represent the model's interaction with surface water features, such as rivers and wetlands. The top layer is underlain by Layer 2 extending from the bottom of Layer 1 to halfway between Layer 1 and the mean sea-level. Layer 3 extended from the bottom of Layer 2 to mean sea-level

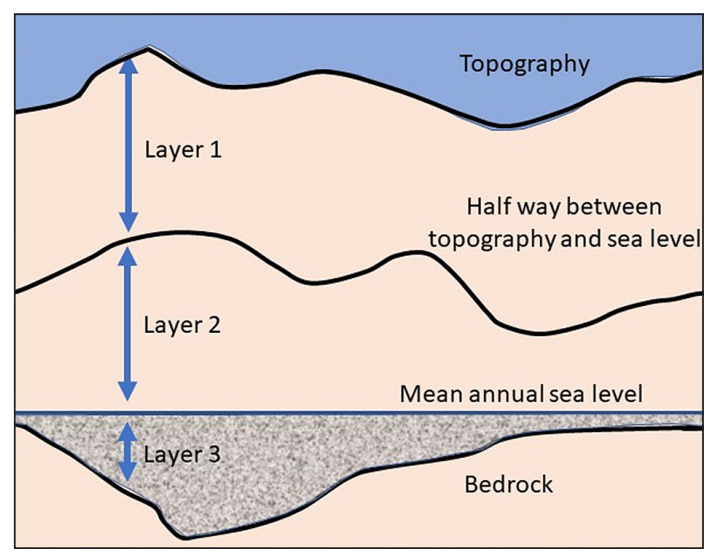

Figure 3. The conceptual hydrogeological model of the CFA developed for the MIKE SHE model and Layer 4 extended from Layer 3 to the basement topography or bedrock. This conceptual hydrogeological model consists of 3 layers, namely, Layers 2, 3 and 4 of those used in the DWAF (2008) study. Since MIKE SHE can represent the unsaturated zone which controls the partition of rainfall into recharge, evaporation and overland flow, this study is able to exclude Layer 1. Additionally, MIKE SHE is linked to MIKE 11, which accounts for the interaction of groundwater and the river network. Therefore, the layering structure is equivalent to that of the DWAF (2008) study, except the uppermost layer, which extends from the topography to halfway between the topography and sea-level and is represented in Fig. 3. While this regional-scale conceptual model is well suited for this type of study, it is acknowledged that furthering modelling studies require a more detailed local-scale conceptual hydrogeological model.

\section{Calibration and validation methods}

In this study the regional-scale model has a resolution of $500 \mathrm{~m}$ and the local-scale model a resolution of $60 \mathrm{~m}$. The regional-scale model was calibrated for a 4-year period (1980 to 1984) which includes groundwater levels, stream flow and water balance data. The MIKE SHE model is capable of simulating both surface- and groundwater hydrological processes (Graham and Butts, 2005). The simulation of surface water processes includes evaporation and overland flow for representing 1-dimensional channel flow (DHI, 2014, 2015). The model domain is represented by a grid of cells which can function at a spatial scale of a single soil profile to a system consisting of several large catchments $\left(>80000 \mathrm{~km}^{2}\right)$.

A visual and statistical comparison of simulated groundwater levels to groundwater level observations indicated that the model could be used to reliably capture seasonal groundwater fluctuations. However, it was clear that the model performed better in boreholes with deeper groundwater levels. Two observed boreholes indicated a coefficient of determination $\left(R^{2}\right)$ of 0.80 and 0.76 , and RMSE of 0.21 and $0.42 \mathrm{~m}$, respectively. Two further boreholes were associated with a relatively high water table, but in this case the model was unable to replicate the magnitude of fluctuations in the observed groundwater levels due to the coarse resolution of the regional-scale model. Both sites showed reasonable representation of the mean groundwater level; however, the minimum and maximum observations were not well simulated. The model was also calibrated to daily streamflow data and compared to past water balance studies to ensure a reasonable representation of the hydrological cycle in MIKE SHE at a regional scale.

Table 1. Summary of data sources used in the model

\begin{tabular}{|c|c|c|}
\hline Parameter & Description & Source \\
\hline Rainfall & $\begin{array}{l}\text { Rainfall data were observed at } 6 \text { locations over the Cape } \\
\text { Flats for the period from } 1980 \text { to } 1984\end{array}$ & $\begin{array}{l}\text { ACRU Agrohydrological Modelling System } \\
\text { (AAHMS); South African Weather Service (SAWS) }\end{array}$ \\
\hline Evapotranspiration & A modified version of the Priestley and Taylor method & Cape Town International Airport \\
\hline Topography & $\begin{array}{l}\text { A } 2 \text { m resolution digital elevation model (DEM) from } \\
\text { LiDAR data of the Cape Flats model area }\end{array}$ & City of Cape Town \\
\hline Vegetation & $\begin{array}{l}\text { The land use and vegetation layer for the calibration } \\
\text { period used the earliest available digital land cover map }\end{array}$ & National Land Cover (2000) \\
\hline Land use & $\begin{array}{l}\text { Primary function to determine how rainfall is partitioned } \\
\text { into different hydrological responses such as infiltration, } \\
\text { runoff and evapotranspiration }\end{array}$ & National Land Cover (2000) \\
\hline Surface water & $\begin{array}{l}\text { Main rivers and excluding minor rivers, local artificial } \\
\text { drainage and stormwater infrastructure }\end{array}$ & $\begin{array}{l}\text { Department of Rural Development and Land } \\
\text { Reform (DRDLR) }\end{array}$ \\
\hline Soil & $\begin{array}{l}\text { The SCS-SA soil map provided the water content at } \\
\text { saturation }\left(\theta_{\mathrm{s}}\right) \text {, field capacity }\left(\theta_{\mathrm{fc}}\right) \text { and wilting point }\left(\theta_{\mathrm{wp}}\right)\end{array}$ & Soil Conservation Service South Africa (SCS-SA) \\
\hline Geology & $\begin{array}{l}\text { Drawn from previous studies describing the stratigraphy } \\
\text { of the Quaternary sands of the Cape Flats through the } \\
\text { analysis of borehole logs }\end{array}$ & $\begin{array}{l}\text { DWAF (2008) provided a detailed analysis of the } \\
\text { stratigraphy; SA Council of GeoScience 1:50 } 000 \\
\text { geological map series }\end{array}$ \\
\hline
\end{tabular}


A validation was performed for a later period (2000-2015) and on two separate monitoring boreholes using the model parameters that were established during the calibration phase. The calibration and validation results indicated that the MIKE SHE model, and its underlying conceptual hydro-geological model, were suitable for further scenario analysis. In addition, the results of the regionalscale model's calibration and validation confirms the current understanding and assumptions of the conceptual hydro-geological model of the CFA, and were based on those used in other studies (Gerber, 1980; Vandoolaeghe, 1989; DWAF, 2008).

The calibrated MIKE SHE model was validated using groundwater-level data obtained from two boreholes (BH): G32961 and G32973. The lengths of these datasets were more extensive than those that were available during the calibration period. $\mathrm{BH}$ G32961 extends almost 12 years, collected from 2004 to 2015, while BH G32973 extends for almost 9 years from 2007 to 2015.
Both boreholes show 'natural' variations in groundwater levels, showing seasonal variation by remaining within an expected $1 \mathrm{~m}$ range of variation over the entire extent of the dataset (See Fig. 4 showing the location of the boreholes).

A visual comparison of the simulated and observed groundwater levels for BH G32961 (Fig. 5) and BH G32973 (Fig. 6) showed a good fit. The simulation showed similar seasonal responses to recharge and rates of decline as the groundwater level drops during dryer periods. For BH G3296, an $R^{2}$ value of 0.73 indicated that the simulated results showed a good fit with the observed data. $\mathrm{BH}$ G32973 showed an excellent fit to the observed data with an $R^{2}$ value of 0.89 . The RMSE for the correlation between simulated results and observed data for BH G32961 is $0.19 \mathrm{~m}$ and $0.17 \mathrm{~m}$ for BH G32973. This indicates that the mean error between each simulated and observed data point is $17 \%$ of the maximum and minimum groundwater levels for BH G32961 and 15\% for that of BH G32973.

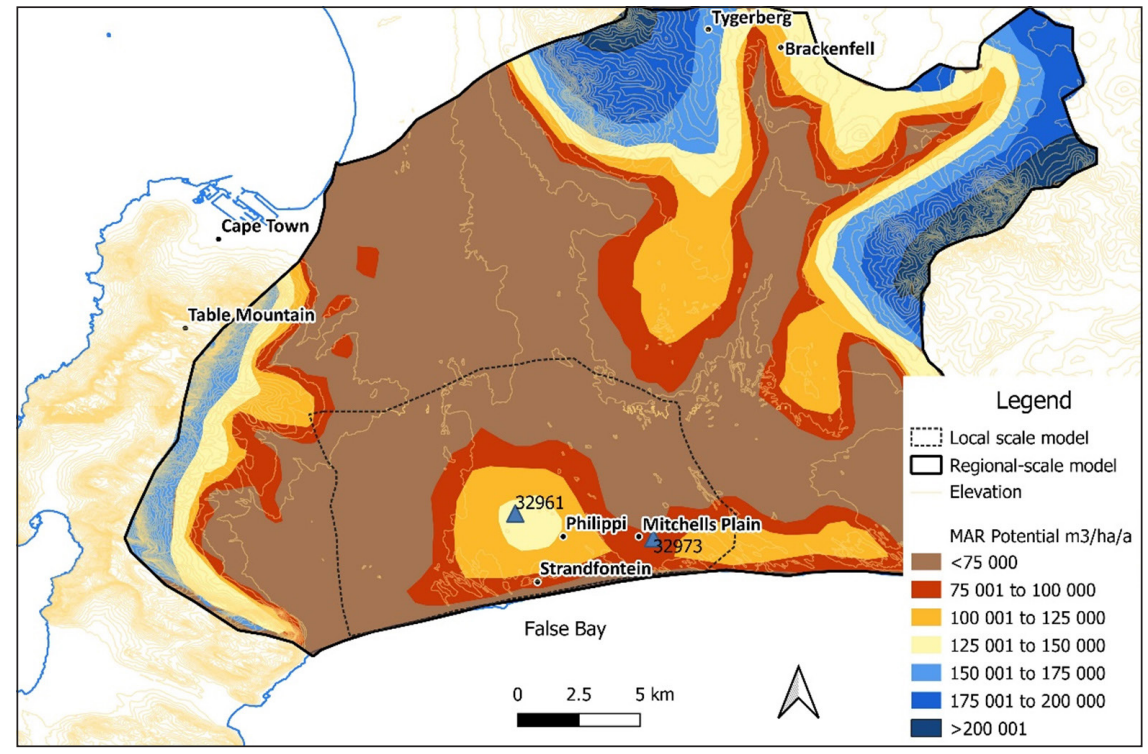

Figure 4. MAR potential for the Cape Flats Aquifer

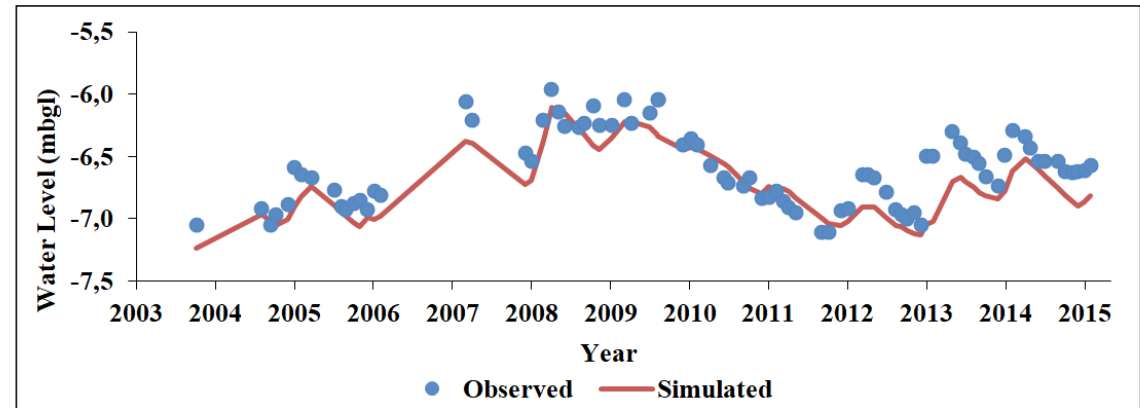

Figure 5. Simulated groundwater levels (metres below ground level) for the Cape Flats and the simulated vs observed groundwater levels for BH G32961 from 2004-2015

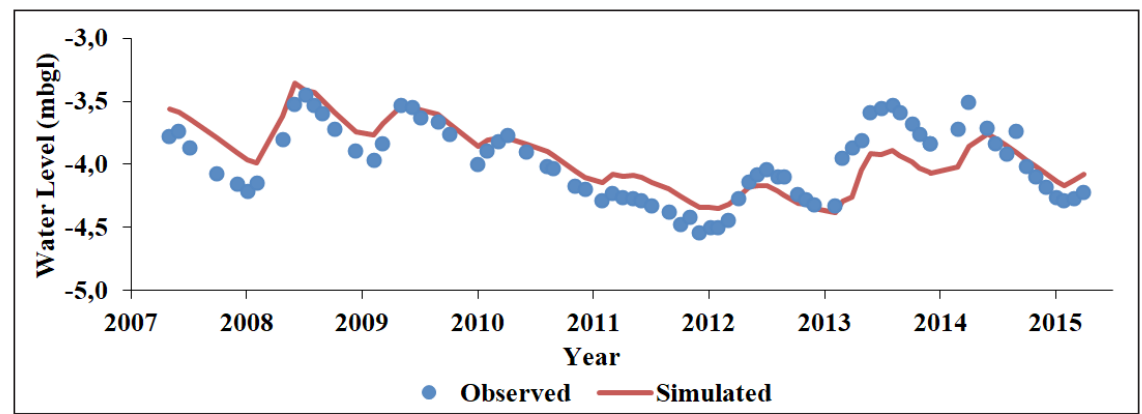

Figure 6. Simulated groundwater levels (metres below ground level) for the Cape Flats and the simulated vs observed groundwater levels for BH G32973 from 2007-2015 


\section{MAR site selection}

A method demonstrated by Murray et al. (2007) was used to calculate the MAR potential of the CFA. This method assumed that MAR was most suitable where there was an additional storage volume within an aquifer. The MAR potential was calculated as half the difference between the 'top of the aquifer' and $5 \mathrm{~m}$ below the mean groundwater level. The mean groundwater level was derived from the regional-scale MIKE SHE model, making it possible to calculate and map the MAR potential of the CFA. The two selected sites at Philippi and Mitchells Plain were identified as best suited for MAR and the feasibility assessment. The aquifer at the Philippi site had the greatest depths of unconsolidated material and therefore had the highest MAR potential. Unconsolidated sands have a high porosity and will increase the infiltration and storage capacity for MAR. Based on the available storage capacity, it was assumed that the greatest opportunity for inter-annual or long-term storage could be found in area surrounding Philippi (Fig. 4), and hence a more detailed scenario analysis was conducted at the Philippi site to simulate the storage processes of the CFA.

\section{MAR scenario analysis}

The first objective in determining the feasibility of MAR on the CFA was to assess the storage properties of the CFA. Based on the high MAR potential at Philippi and Mitchells Plain, it was hypothesised that these areas may provide a valuable form of short-term and long-term storage. However, the bulk of the storage analysis was carried out on the Philippi site as this region of the CFA was associated with the highest storage or MAR potential and therefore it was assumed that it held the greatest opportunity for both short- and long-term storage at Philippi.

The annual artificial recharge volume was increased incrementally by $2 \mathrm{Mm}^{3} \cdot \mathrm{yr}^{-1}$, which extended from $2 \mathrm{Mm}^{3} \cdot \mathrm{yr}^{-1}$ to $10 \mathrm{Mm}^{3} \cdot \mathrm{yr}^{-1}$, and the change in storage in the saturated zone was evaluated for each recharge scenario. The artificial recharge was applied to the soil surface as 'rainfall' at a depth equivalent to the daily volume of recharge. The infiltrated recharge was applied to an area of $280000 \mathrm{~m}^{2}$ overlying the Philippi site which represented a large infiltration basin. An additional method of aquifer recharge was simulated via direct injection into boreholes or wellpoints. The size of the wellfield was a function of three factors: the intended annual recharge volume; allowable borehole yield or abstraction rate; and the storage capacity of the aquifer. Since this study investigated the storage potential of the CFA for winter stormwater management, the simulated groundwater recharge was restricted to 184 days during the winter rainfall months. The maximum borehole yield in the southern parts of the CFA near Philippi is approximately $32 \mathrm{~L} \cdot \mathrm{s}^{-1}$ with an estimated sustainable yield of approximately $17 \mathrm{~L} \cdot \mathrm{s}^{-1}$ (Tredoux et al. 1980; Vandoolaeghe, 1989). Thus, in designing the wellfield at Mitchell's Plain, 20 boreholes were used to maximise the recharge volume, given the limits of these injection and abstraction rates. Furthermore, the same limits that were applied to the injection rates were also applied to the abstraction rates, but this does not account for fluxes in the table which would affect the available yield compared to the volume of injection. The study is a proof of concept and does not account, for example, for the realities of injection, such as hydraulic resistance and arrangement of the boreholes.

Three recharge and abstraction scenarios (Scenarios 2, 3 and 4) (Table 2) were simulated to test the feasibility of MAR for seasonal stormwater storage and reuse. Scenario 2 is a relatively conservative MAR scenario for simulating winter recharge at a rate of $15 \mathrm{~L} \cdot \mathrm{s}^{-1}$ and a summer abstraction rate of $15 \mathrm{~L} \cdot \mathrm{s}^{-1}$ based on a total annual recharge volume of $5 \mathrm{Mm}^{3}$, which is within the range of preventing losses (based on 3 ) and the suggested sustainable pumping rate of $17 \mathrm{~L} \cdot \mathrm{s}^{-1}$ (Tredoux et al. 1980; Vandoolaeghe, 1989). Scenario 3 excluded recharge and therefore simulated only groundwater abstractions at the maximum rate of approximately $32 \mathrm{~L} \cdot \mathrm{s}^{-1}$ during the summer months. Scenario 4 combines the two previous scenarios by assessing the impact of maximum abstractions at a rate of $32 \mathrm{~L} \cdot \mathrm{s}^{-1}$ during summer while incorporating winter recharge at $15 \mathrm{~L} \cdot \mathrm{s}^{-1}$. Scenarios 5 and 6 assess the best-performing scenarios at the Philippi site and evaluated the feasibility under different aquifer conditions at Mitchells Plain. Scenario 5 is the same as Scenario 3 but excludes recharge and simulates only groundwater abstractions at the maximum rate of approximately $32 \mathrm{~L} \cdot \mathrm{s}^{-1}$ during the summer months. Scenario 6 is equivalent to Scenario 4, which assesses the impact of maximum abstractions at a rate of $32 \mathrm{~L} \cdot \mathrm{s}^{-1}$ during summer while incorporating a winter recharge at $15 \mathrm{~L} \cdot \mathrm{s}^{-1}$.

\section{RESULTS}

\section{MAR potential for the CFA}

The regional-scale model output described previously allowed for the MAR potential of the CFA to be determined using the simulated mean head elevation for the period from 2000-2015. The method demonstrated by Murray et al. (2007) was used to calculate the MAR potential of the CFA (Fig. 3). This method assumes that MAR is most suitable in an aquifer where there is an additional storage volume due to lack of natural recharge. The MAR potential was calculated as half the difference between the 'top of the aquifer' and $5 \mathrm{~m}$ below the mean groundwater level. The top of the aquifer was the theoretical maximum groundwater level after which additional recharge was lost as drainage. The 'top of the aquifer' was derived by simulating the groundwater levels using an artificially high rainfall dataset. This dataset involved doubling the daily rainfall for 2007 , which was the wettest year between 2000 and 2015, and running the model with that data for 15 years. The mean groundwater levels were calculated using the 15-year MIKE SHE simulation of groundwater levels from 2000 to 2015 under baseline conditions.

The simulated MAR potential was highest in those areas that have the highest topographic elevation, such as Table Mountain in the west and the hills of the Tygerberg area in the north and northeast. However, these areas are associated with aquifer conditions beyond the scope of this study, as they are fractured aquifers and

Table 2. Summary of the scenario descriptions for MAR at Philippi and Mitchells Plain

\begin{tabular}{|c|c|c|c|c|c|}
\hline Scenario & Site & $\begin{array}{l}\text { Abstraction } \\
\text { volume }\end{array}$ & $\begin{array}{l}\text { Recharge } \\
\text { volume }\end{array}$ & Time & MAR process \\
\hline Scenario 1 & Philippi and Mitchells Plain & $2 \mathrm{Mm}^{3}$ to $10 \mathrm{Mm}^{3}$ & $2 \mathrm{Mm}^{3}$ to $10 \mathrm{Mm}^{3}$ & Winter months & Infiltration \& injection \\
\hline Scenario 2 & Philippi and Mitchells Plain & $15 \mathrm{~L} \cdot \mathrm{S}^{-1}$ & $15 \mathrm{~L} \cdot \mathrm{S}^{-1}$ & Summer \& Winter & Abstraction \& recharge \\
\hline Scenario 3 & Philippi & $32 L \cdot \mathbf{S}^{-1}$ & No recharge & Summer & Abstraction \\
\hline Scenario 4 & Philippi & $32 \mathrm{~L} \cdot \mathrm{S}^{-1}$ & $15 \mathrm{~L} \cdot \mathrm{S}^{-1}$ & Double summer \& winter & Abstraction \& recharge \\
\hline Scenario 5 & Mitchells Plain & $32 L \cdot s^{-1}$ & - & Summer & Abstraction \\
\hline Scenario 6 & Mitchells Plain & $32 L \cdot S^{-1}$ & $15 \mathrm{~L} \cdot \mathbf{S}^{-1}$ & $\begin{array}{l}\text { Double summer \& winter } \\
\text { recharge }\end{array}$ & Abstraction and recharge \\
\hline
\end{tabular}


the MIKE SHE model has not been optimised for these conditions. Thus, the main interest for MAR mapping is within the primary aquifer of the Cape Flats Quaternary sands, the aquifer unit for which this MIKE SHE model was calibrated and validated. The results of this mapping indicate that the highest MAR potential exists in the southern parts of the CFA, showing between $75000 \mathrm{~m}^{3} \cdot \mathrm{ha}^{-1} \cdot \mathrm{yr}^{-1}$ to over $150000 \mathrm{~m}^{3} \cdot \mathrm{ha}^{-1} \cdot \mathrm{yr}^{-1}$. These are areas where the aquifer has greater depth to the bedrock topography and higher topographic elevation. The Philippi MAR site exhibits a particularly large storage volume available for MAR due to the presence of a paleochannel that runs in a north-south direction below much of the central parts of the CFA. This depression in the bedrock topography, together with the increasing elevation of surface topography towards the False Bay coastline, marks the thickest parts of the CFA (approx. $55 \mathrm{~m}$ ). The areas has a MAR potential of less than $75000 \mathrm{~m}^{3} \cdot \mathrm{ha}^{-1} \cdot \mathrm{yr}^{-1}$.

It is important to note that the method used by Murray et al. (2007) was developed to assess MAR potential on a national scale and thus is a conservative estimate of MAR potential. It is anticipated that the upper recharge limit - half the difference between the 'top of the aquifer' and $5 \mathrm{~m}$ below the mean groundwater level and lower drawdown limit of $5 \mathrm{~m}$ can be applied to the CFA with reasonable confidence.

\section{Philippi: CFA recharge-storage potential}

Initial results for Scenario 1 indicated that both the infiltrated and injected recharge scenarios showed proportional increases in storage depth with increasing volumes of recharge (Fig. 7). The injection scenario showed greater storage with increasing recharge as it was applied over a larger area than the infiltrated recharge, meaning that the same volume was distributed evenly throughout the available storage in the aquifer. This resulted in a smoother hydraulic gradient, compared to the infiltrated recharge, and showed an improvement in the storage potential. The proportional relationship continued until a recharge volume of approximately $6 \mathrm{Mm}^{3}$ per year, after which the storage potential of the recharge began to decline due to losses. These losses affect the infiltrated scenario to a greater extent, where the storage potential was reduced earlier at a recharge volume of $4 \mathrm{Mm}^{3}$ per year. Thus, the optimum storage for the injected MAR and infiltrated storage MAR is $237 \mathrm{~mm}$ and $149 \mathrm{~mm}$, respectively. Therefore, the direct injection scenario was likely to be more efficient than the infiltration MAR strategy.
The long-term storage potential of the CFA at the Philippi site was evaluated using two additional scenarios that aimed to recharge stormwater into the CFA for long-term storage, also known as water 'banking. The scenarios were based on a conservative recharge rate of $5 \mathrm{Mm}^{3}$ per year or $15.72 \mathrm{~L} \cdot \mathrm{s}^{-1}$ during the winter months. Three recharge periods were selected for the following years: (i) 2000 to 2015; (ii) 2000 to 2006; and (iii) 2000 to 2009 (Fig. 8). The first case was to assess the impact of continuous seasonal recharge for the duration of the simulation period for comparison purposes. In this case, the increase in storage from winter recharge reached a peak after approximately 9 years in 2009, indicating the upper limit to the amount of storage that is possible and its recharge rate. In Cases 2 and 3 , after 6 and 9 years, respectively, summer abstractions were initiated to simulate the demand for stored water after the recharge period which, for example, might occur in a season of prolonged drought. The availability of the stored water was evaluated on the length of time between the initial abstraction in summer and the point to which the storage of the CFA declined until it intersected the simulated baseline storage (Fig. 8). In Case 2, after 6 years of recharge, abstraction occurred for 3 years and 1 month, and declined to below the baseline level in February 2009. However, in Case 3, following 9 years of recharge, abstraction occurred for 3 years and 10 months, but declined to below the baseline level in November 2009. These results indicated that the amount of retrievable stored water is proportional to the amount of recharge, where an increase of 3 years' worth of recharge, from 6 to 9 years, resulted in 10 months or one additional season of abstraction.

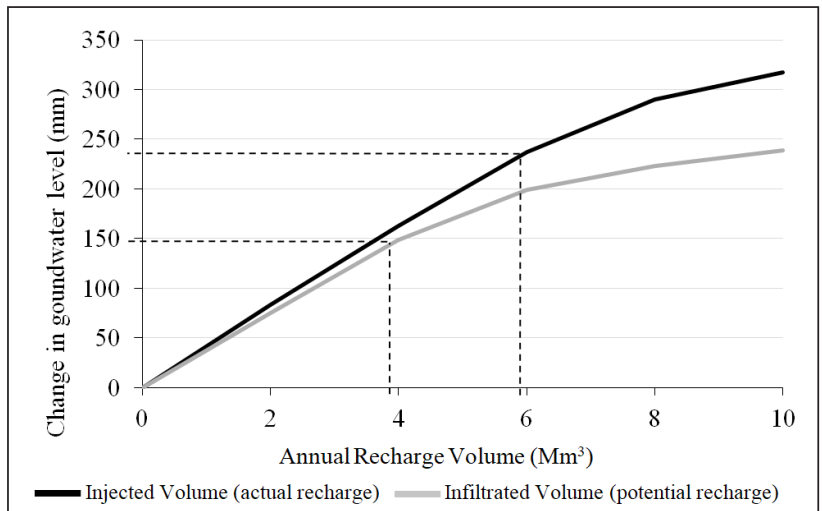

Figure 7. Potential recharge-storage relationship for the Philippi MAR site using infiltration and direct injection (Scenario 1)

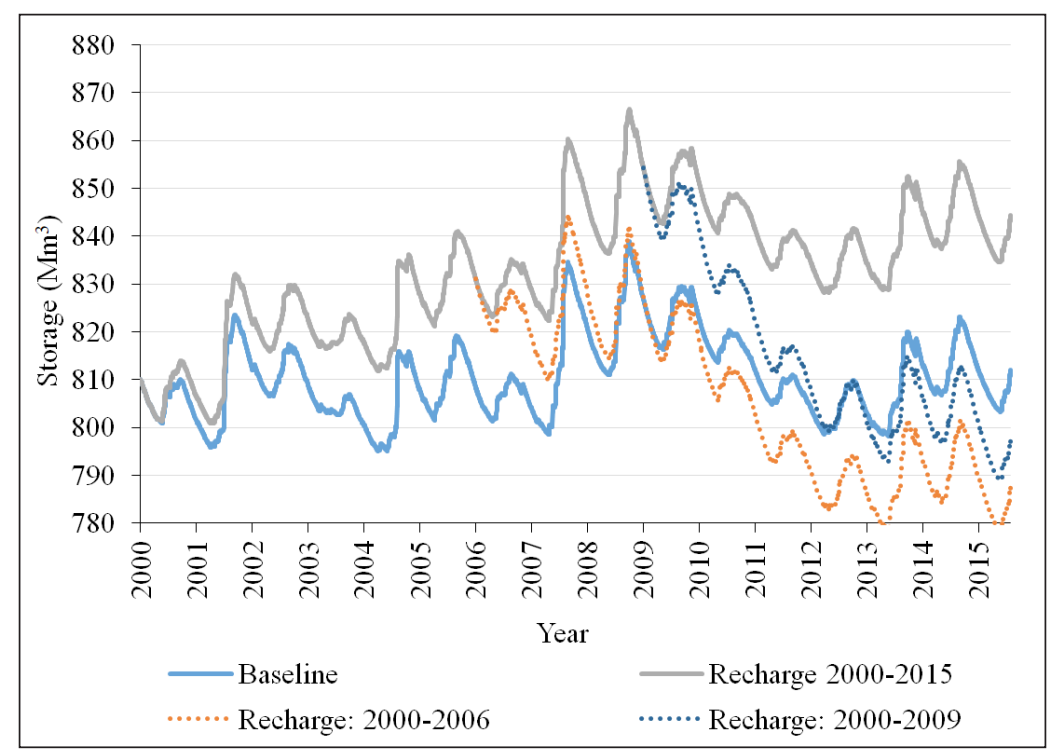

Figure 8. The long-term storage of the CFA at the Philippi site comparing recharge at $5 \mathrm{Mm}^{3}$ per year for 6,9 and 15 years, respectively (Case 1, 2 and 3) 


\section{Philippi and Mitchells Plain wellfield yield}

The objective of the scenario analysis was to assess the potential of the CFA to store stormwater on a shorter-term basis, in which winter recharge is made available for reuse in the following summer months. Thus, the following section examines 5 recharge and abstraction scenarios at 2 sites as suggested for MAR from this study. Scenarios 2, 3 and 4 were conducted at the Philippi site, while Scenarios 5 and 6 were simulated at the Mitchells Plain site.

The yield for each of the scenarios was assessed based on the accumulated abstractions. Although a given abstraction rate was specified in a particular simulation, due to the wellfield arrangement including the aquifer characteristics and abstraction schedule, some of the boreholes within the wellfield could run dry. In this event, abstraction ceases until the groundwater levels recover to the point where pumping can resume. The expected yield of the wellfield for the simulation period was approximately $77 \mathrm{Mm}^{3}$ for Scenario 2, while the expected wellfield yield for Scenarios 3 and 4 is approximately $154 \mathrm{Mm}^{3}$ due at the same pumping rate that was used in both scenarios. The actual wellfield yield of Scenario 2 is equal to the expected yield and indicated that the boreholes in this scenario did not run dry and therefore this scenario had $100 \%$ abstraction potential. However, Scenario 3 had a reduced potential in which only $87 \%$ of the intended volume could be abstracted because the boreholes occasionally ran dry (Table 3). The recharge of the CFA during the winter months resulted in an increase in groundwater levels prior to the summer abstraction period, thereby preventing boreholes in the wellfield from running dry and ensuring the expected wellfield yield was achieved.

Given the potential increases in wellfield yield by using MAR, as demonstrated by Scenario 4, the next phase in the study was to assess if these results could be transferred to Mitchells Plain. Scenarios 5 and 6 were simulated at Mitchells Plain and consisted of the same simulation procedure as those conducted for Scenarios 3 and 4 at the Philippi site. The expected yield for both scenarios was $154 \mathrm{Mm}^{3}$; however, both scenarios show reduced yields when compared to the corresponding scenarios at Philippi, with Scenario 5 showing a $48 \%$ reduction compared to Scenario 2 , and Scenario 6 showing a 21\% reduction compared to Scenario 4. The reduction is explained by the reduced aquifer thickness at Mitchells Plain resulting in less storage volume around the wellfield to maintain borehole yields. The implementation of MAR did improve the wellfield yield by $39 \%$; however, considering the recharged volume was $50 \%$ of the abstracted volume, this suggests that the return on the recharged water was not observed.

The results from the wellfield yield were corroborated by the accumulated abstractions for Scenarios 2, 3 and 4 at Philippi (Fig. 9). Scenario 2 showed consistent pumping and rates until the total of $77 \mathrm{Mm}^{3}$ was achieved, during which time there were no incidents of the boreholes running dry. Scenarios 3 and 4 showed similar increases in the initial stages of the model simulation up until 2004. After 2004, Scenario 3 showed reduced groundwater levels in the aquifer, to the extent that the boreholes began to dry out and with an increasing decline in yield from the wellfield. Alternatively, Scenario 4 maintained the specified abstraction rates and did not experience any declines in yield because of the drying boreholes. The accumulated abstractions were significantly lower at Mitchells Plain compared to the equivalent pumping rate at Philippi (Scenario 3). After 15 years, the wellfield yield was even less than the conservative MAR scenario. An addition of $5 \mathrm{Mm}^{3}$ of stormwater recharge showed increases in the accumulated yield, but it remained well below the yields experienced at Philippi. Scenario 5, which is equivalent to Scenario 6, considered only summer abstraction at the maximum rate of $10 \mathrm{Mm}^{3}$ per year. At this rate, the wellfield was not able to maintain the abstraction rate because the boreholes became dry. The potential MAR of this wellfield was approximately $48 \%$ of the anticipated yield. When $5 \mathrm{Mm}^{3}$ per year of stormwater was used to offset these losses in Scenario 6, the potential of the wellfield improved to $79 \%$, but only by $39 \%$ from the abstraction-only scenario (i.e. Scenario 5 ). Thus, the infiltration of this volume of water was inefficient as it meant that only $61 \%$ of the infiltrated water was available during the summer months for abstraction. Steep bedrock typography created a high hydraulic gradient in the area, and consequently, the rapid flow of injected water towards the False Bay coastline.

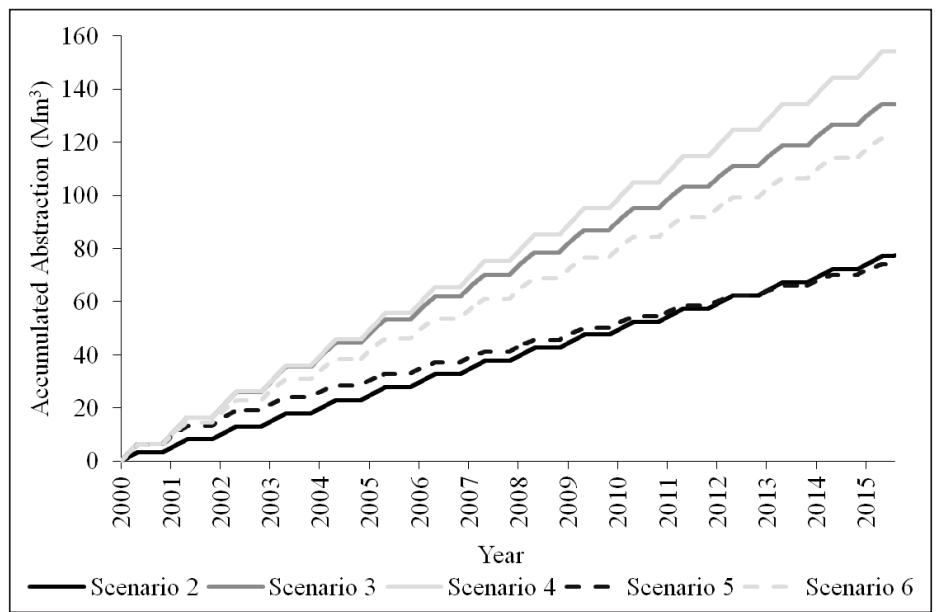

Figure 9. Accumulated abstracted water volume for Scenarios 2, 3, 4, 5 and 6

Table 3. The wellfield yields for MAR scenarios at Philippi and Mitchell Plain

\begin{tabular}{|c|c|c|c|c|}
\hline Scenario & MAR site & Expected wellfield yield $\left(\mathrm{Mm}^{3}\right)$ & Actual wellfield yield $\left(\mathrm{Mm}^{3}\right)$ & MAR potential (\%) \\
\hline Scenario 2 & Philippi & 77 & 77 & 100 \\
\hline Scenario 3 & Philippi & 154 & 134 & 87 \\
\hline Scenario 4 & Philippi & 154 & 154 & 100 \\
\hline Scenario 5 & Mitchells Plain & 154 & 74 & 48 \\
\hline Scenario 6 & Mitchells Plain & 154 & 121 & 79 \\
\hline
\end{tabular}




\section{Recharge-storage relationship}

Since the Philippi site was shown to have the greatest MAR potential, it was important to determine the upper limits of the recharge potential of the CFA based on the recharge-storage relationship at this site, and to compare the two methods of recharge, viz., injection and infiltration. This process involved incrementally increasing the amount of winter stormwater recharge, applied as infiltration or injection, and simulating the change in the aquifer storage. By simulating incremental increases in recharge, it is possible to isolate the point at which the proportional relationship between recharge and storage ceases, and in which increasing volumes of artificially recharged water result in diminishing increases in aquifer storage.

The results indicated that the direct injection method of recharge was more efficient than the infiltration method, showing greater storage for each volume of water recharged. This was attributed to the greater volume of aquifer storage utilised in the injection method when compared to the infiltration method. The available storage volume in the aquifer was reduced using the infiltration method, due to the sharper 'mounding' of the water table because of the slower infiltration process, whereas in the case of the injected water, the aquifer is recharged almost instantaneously and the increase in pressure more rapidly facilitates the dissemination of water throughout the aquifer resulting in a higher storage potential (Fig. 10). The greater level of 'mounding' meant that the drainage losses for infiltrated recharge occurred at lower recharge volumes than in the injected recharge, since the higher groundwater levels began to intersect with local topography above $4 \mathrm{Mm}^{3}$. The injection method of recharge was found to only start incurring drainage losses after $6 \mathrm{Mm}^{3}$, which suggested that injection would be a more efficient method for stormwater recharge for MAR on the CFA. Two MAR methods of recharge, injection and infiltration used the maximum winter recharge rate for the Philippi site of $10 \mathrm{Mm}^{3}$ per year (Fig. 10). The maximum volume illustrates the effects of the steeper hydraulic gradient in the infiltration scenario resulting in the 'mounding' effect which leads to increased losses from interflows. At this recharge volume, the injection method also incurs losses; however, this is mitigated as more of the aquifer is used for the storage of recharge water from the smoother hydraulic gradient and less pronounced mounding effects.

\section{Seawater intrusion}

Due to the proximity of the Philippi and Mitchells Plain MAR sites to the False Bay coast, it was necessary to account for the risk of seawater intrusion. The change in simulated hydraulic gradient and the extent and magnitude of the cone of depression were evaluated to assess the risk of seawater intrusion. Model simulations showed that the minimum groundwater head elevation for the baseline conditions indicated a strong hydraulic gradient towards the False Bay coastline. The hydraulic head elevation for Scenario 2 indicated minimal drawdown at the Philippi MAR site. Thus, the hydraulic gradient along the False Bay coastline remains largely unaffected by the recharge and abstraction at the MAR site. Furthermore, there were indications of an increase in groundwater head elevation at the MAR site and an increase in groundwater head elevation which indicated a potential interflow of groundwater. Scenario 3 characterized the upper limit of the possible drawdown using the 20-borehole wellfield and pumping at $32 \mathrm{~L} \cdot \mathrm{s}^{-1}$ during the summer months. Scenario 3 showed a significant drawdown at the MAR site to $-5 \mathrm{~m}$ below sea-level of approximately $-16 \mathrm{~m}$. The hydraulic gradient between Philippi and the coast is reduced in Scenario 3, yet the hydraulic gradient still maintained a northsouth inclination. The preservation of the hydraulic gradient at Philippi indicated that seawater intrusion is unlikely. However, if the groundwater drawdown is consistently below sea level, there may be a risk of saltwater up-coning. To minimise the risk of seawater intrusion and to maximise the amount of water available for abstraction, an additional MAR scenario (Scenario 4) was simulated that consisted of summer abstractions at $32 \mathrm{~L} \cdot \mathrm{s}^{-1}$ while the injected winter recharge was simulated at $15 \mathrm{~L} \cdot \mathrm{s}^{-1}$. It was assumed that a lower recharge rate would reduce the cost of recharging water while still maintaining a sustainable yield of approximately $10 \mathrm{Mm}^{3}$ at the maximum abstraction rate.

The simulated cone of depression and groundwater elevation profile for Scenario 4 indicated that the recharge offset the drawdown effect that was observed in Scenario 3. The maximum drawdown for Scenario 4 was half of Scenario 3 at approximately $-8 \mathrm{~m}$ with an average of between -6 and $-8 \mathrm{~m}$ for a large portion of the MAR area. Furthermore, the reduction in drawdown ensured that the cone of depression did not extend below sealevel, thereby reducing the risk of seawater intrusion.

The impact of the drawdown in Scenarios 5 and 6 at Mitchells Plain was also examined. Scenario 5 represents the mean drawdown under maximum summer pumping conditions $\left(32 \mathrm{~L} \cdot \mathrm{s}^{-1}\right)$ with no winter recharge. The mean drawdown under this scenario was between -12 and $-10 \mathrm{~m}$, which was less than the same abstraction rate in Scenario 3 at the Philippi site. The reason for the reduced drawdown impact was because of the shallower aquifer depth at Mitchells Plain, that is, the boreholes dried out faster due to the weaker hydraulic gradient in the vicinity of the Mitchells Plain wellfield. Similar impacts were seen in Scenario 6; however, due to the additional winter recharge, the drying out of boreholes was less frequent. Scenario 6 showed a drawdown of between -4 and $-6 \mathrm{~m}$, which was only 1-2 $\mathrm{m}$ higher than that of Scenario 4 . Moreover, the groundwater elevation for both Scenarios 5 and 6 showed that they were well above sea-level and indicated a limited risk of seawater intrusion and up-coning of seawater into the boreholes.

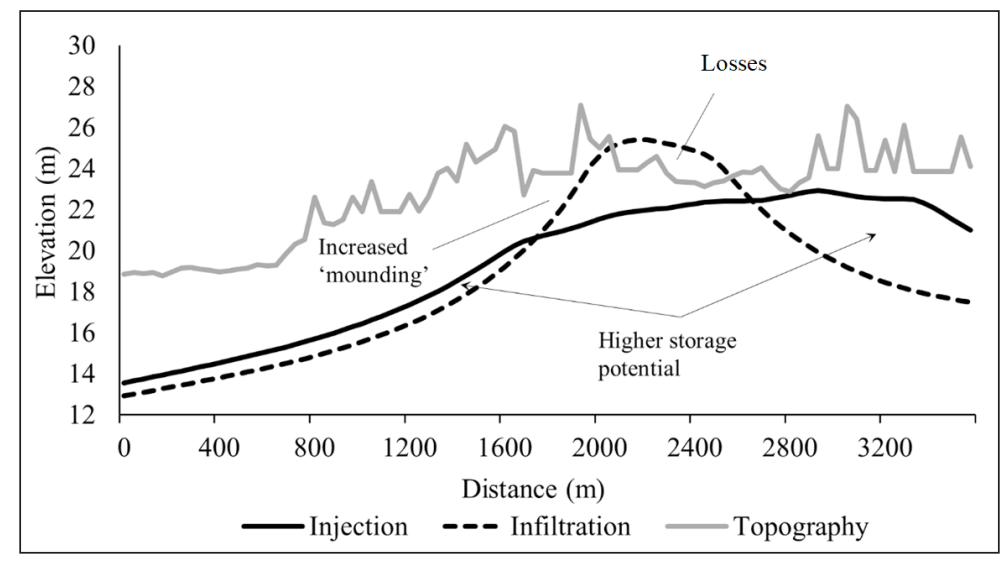

Figure 10. An elevation profile through the Philippi MAR site comparing injection and infiltration of $10 \mathrm{Mm}^{3}$ per year in relation to the topographic elevation 
This was primarily due to the strong north to south hydraulic gradient and the elevated bedrock in the area which will reduce or limit the risk of seawater flowing in a northerly direction into the CFA. While the risk of seawater intrusion is reduced by maintaining the hydraulic gradient, this study has not represented other factors that could influence seawater intrusion such as water density and undulating bedrock.

\section{DISCUSSION}

The southern parts of the CFA near Philippi and Mitchells Plain were found to be the most feasible areas for implementation of MAR. The CFA at the Philippi site was tested by using a series of recharge scenarios that assessed the storage-recharge relationship (Scenario 1). It was found that recharge via injection is more efficient than recharge via infiltration. By reducing losses, MAR from injection increased the total storage to $6 \mathrm{Mm}^{3}$ compared to $4 \mathrm{Mm}^{3}$ using the infiltration method. These storage results showed that Philippi has the storage capacity to contain large volumes of stormwater in the short- and long-term (Figs 7 and 8).

MAR Scenarios 2, 3 and 4 were tested to demonstrate the potential for MAR to minimise the risk of seawater intrusion and maximise the amount of water available for abstraction from the CFA. Scenarios 5 and 6 could also be implemented in the adjacent Mitchells Plain area as another potential MAR site, although the aquifer is shallower. It was shown that MAR could improve the yield of the CFA at Mitchells Plain; however, MAR at this site was less efficient than at the Philippi site. To improve the potential of recovering recharged water at Mitchells Plain, an option would be to move the injection boreholes further north or up-gradient of the abstraction site to prevent losses of injected water. The steep nature of the bedrock and strong hydraulic gradient of the CFA at Mitchells Plain makes seawater intrusion unlikely. Furthermore, the bedrock underlying the aquifer, although fractured and which should not be assumed to form a homogeneous aquitard, is elevated above the sea-level. A strong reversal of the hydraulic gradient would be required for seawater intrusion to occur. This is unlikely even under maximum abstraction where the hydraulic gradient was only weakened, but not reversed.

The MAR scenarios (Scenarios 1-6) at Philippi and Mitchells Plain provide strong evidence to suggest that there is sufficient storage capacity within the CFA for the application of reuse strategies using stormwater. MAR was shown to improve the wellfield yield at Philippi and Mitchells Plain, resulting in a total sustainable yield of approximately $18 \mathrm{Mm}^{3}$ per year without risking seawater intrusion. MAR may also prove to be a valuable strategy for dealing with the impacts of climate change. Many of the current climate predictions for Cape Town foresee a warmer and drier future climate, which will result in declining groundwater recharge and storage. The implementation of MAR could help to mitigate the impacts of climate change on groundwater resources, while providing an effective form of storage to prevent evaporative losses.

\section{CONCLUSION}

The CoCT is committed to establishing a water-resilient city by 2030 that aims to integrate the urban water cycle and include the optimal use of stormwater for flood control, aquifer recharge and water reuse, while also protecting sensitive natural ecosystems (CoCT, 2019). Improved stormwater management will be essential for achieving the CoCT's objectives which must include capturing and storing water underground for productive and 'fit for purpose' water reuse. This study has shown that MAR has the potential to contribute a yield of approximately $50 \mathrm{M} \mathrm{L} \cdot$ day $^{-1}$ $\left(18 \mathrm{Mm}^{3 \cdot y r-1}\right)$ which could offset the CoCT's investment in waterrelated infrastructure over the next 10 years in its plan to increase the available water supply by $300 \mathrm{ML} \cdot \mathrm{day}^{-1}$. The success of MAR in the CFA will have to demonstrate that the future management of injected or infiltrated stormwater and treated wastewater is a viable water resource that can contribute to the development of a water-resilient city. Groundwater in aquifers like the CFA will become increasingly more difficult to ignore, given the long-term projections of climate change, but even in the short term because the implementation of MAR aims to increase the efficiency and value of water resources to meet the increasing demand. As a result, MAR is an opportunity and an incentive for the inclusion of groundwater in supporting plans to build a water-resilient city. The results from this study suggest that MAR is a viable water supply option for Cape Town, provided further field testing at selected sites is performed to determine the potential effect and impact of directly recharging and abstracting from the CFA.

\section{ACKNOWLEDGEMENTS}

The authors wish to acknowledge the financial support of the Water Research Commission that enabled the first author to complete a doctoral thesis on the topic that is presented in this paper. The authors are grateful for the constructive and insightful comments that were given by two anonymous reviewers on the first draft of this paper.

\section{REFERENCES}

BROWN R, KEATH N and WONG T (2008) Transitioning to water sensitive cities: historical, current and future transition states. In: $11^{\text {th }}$ International Conference on Urban Drainage, 31 August - 5 September 2008, Edinburgh. 1-10.

CoCT (City of Cape Town) (2013) Annual WSDP Performance Services Audit Report. City of Cape Town.

CoCT (City of Cape Town) (2017) Community Survey Cape Town Trends 1996 to 2016. Research Branch, Organisational Policy and Planning Department, City of Cape Town. URL: http://resource. capetown.gov.za/documentcentre/Documents/Maps\%20and\%20 statistics $/ 2016 \% 20$ Community\%20Survey\%20Cape $\% 20$ Town $\% 20$ Trends.pdf

CoCT (City of Cape Town) (2019) Our Shared Water Strategy. City of Cape Town. URL: https://resource.capetown.gov.za/documentcentre/Docu ments/City\%20strategies,\%20plans\%20and\%20frameworks/Cape\% 20Town\%20Water\%20Strategy.pdfhttps://resource.capetown.gov.za/ documentcentre/Documents/City\%20strategies,\%20plans\%20and\% 20frameworks/Cape\%20Town\%20Water\%20Strategy.pdf

CURRIE PK, MUSANGO JK and MAY ND (2017) Urban metabolism: a review with reference to Cape Town. Cities. 70 91-110. https://doi. org/10.1016/j.cities.2017.06.005

DHI (Danish Hydraulic Institute) (2014) MIKE SHE User Manual Volume 1: User Guide. Horsholm, Denmark.

DHI (Danish Hydraulic Institute) (2015) MIKE 11: User Guide. Horsholm, Denmark.

DILLON P, PAVELIC P, PAGE D, BERINGEN H and WARD J (2009) Managed Aquifer Recharge: An Introduction. CSIRO, Canberra.

DWAF (Department of Water Affairs and Forestry, South Africa) (2008) The Assessment of Water Availability in the Berg Catchment (WMA 19) by Means of Water Resource Related Models: Groundwater Model Report Volume 5 - Cape Flats Aquifer Model. Prepared by Umvoto Africa (Pty) Ltd in association with Ninham Shand (Pty) Ltd. Pretoria, South Africa.

DWAF (Department of Water Affairs and Forestry, South Africa) (2009) Water for Growth \& Development Framework. DWAF, Pretoria.

ENQVIST J and ZIERVOGEL G (2019) Water governance and justice in Cape Town. Wiley Interdisc. Rev. Water. 6 (4) e1254. https://doi. org/10.1002/wat 2.1354

GRAHAM DN and BUTTS MB (2005) Flexible, integrated watershed modelling with MIKE SHE. In: Singh VP and Frevert DK (eds) Watershed Models. CRC Press, Boca Raton. 1-25.

MAUCK BA (2017) The capacity of the Cape Flats Aquifer and its role in water sensitive urban design in Cape Town. $\mathrm{PhD}$ thesis, University of Cape Town. 
MURRAY R, TREDOUX G, RAVENSCROFT P and BOTHA F (2007) Artificial Recharge Strategy. Department of Water Affairs and Forestry, Pretoria.

PAGE D, GONZALEZ D, DILLON P, VANDERZALM J, VADAKATTU G, TOZE S, SIDHU J, MIOTLINSKI K, TORKZABAN S and BARRY K (2013) Managed Aquifer Recharge and Stormwater Use Options (MARSUO): Public health risk assessment. Goyder Institute for Water Research, Adelaide.

REBELO AG, HOLMES PM, DORSE C and WOOD J (2011) Impacts of urbanization in a biodiversity hotspot: Conservation challenges in Metropolitan Cape Town. S. Afr. J. Bot. 77 (1) 20-35. https://doi. org/10.1016/j.sajb.2010.04.006

ROGERS J (2018) Geological Adventures in the Fairest Cape: Unlocking the Secrets of its Scenery. Council for Geoscience, Pretoria.

SCHULZE RE, MAHARAJ M, WARBURTON ML, GERS CJ, HORAN MJC, KUNZ RP and CLARKE DJ (2008) Electronic data accompanying the South African Atlas of Climatology and Agrohydrology. WRC Report No. 1489/1/08. Water Research Commission, Pretoria.

SINCLAIR-SMITH K and WINTER K (2019) Water demand management in Cape Town: Managing water security in a changing climate. In: Scott D, New M and Davies H (eds) Mainstreaming Climate Change in Urban Development. Juta, Cape Town.
TREDOUX G, ROSS R and GERBER A (1980) The potential of the Cape Flats Aquifer for the storage and abstraction of reclaimed effluents (South Africa). Z. Deutsch. Geol. Ges. 131 23-43. https:// doi.org/10.1127/zdgg/131/1980/23

VANDOOLAEGHE MAC (1989) The Cape Flats groundwater development pilot abstraction scheme. Technical Report No. GH3655, Directorate Geohydrology, Department of Water Affairs and Forestry, Cape Town.

WOLSKI P (2018) How severe is Cape Town's 'Day Zero' drought? Significance April 2018 24-27. https://doi.org/10.1111/j.1740-9713. 2018.01127. $\mathrm{x}$

WONG T and BROWN R (2008) Transitioning to Water Sensitive Cities: Ensuring Resilience through a new Hydro-Social Contract. In: $11^{\text {th }}$ International Conference on Urban Drainage. Edinburgh, Scotland, 1-10.

ZHAO H (2012) Application of MIKE SHE/MIKE 11 Model to Structural BMPs in S191 Basin, Florida. J. Environ. Inf. 19 (1) 10-19. https://doi.org/10.3808/jei.201200204 